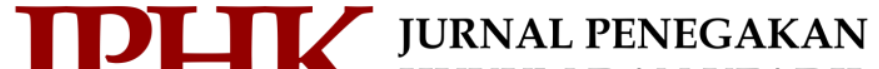 HUKUM DAN KEADILAN}

Vol. 2 No. 2, September 2021, Hal. 147-161

P-ISSN: 2746-0967, E-ISSN: 2721-656X
Gedung Pascasarjana Kampus Terpadu UMY Jalan Brawijaya, Tamantirto, Kasihan, Bantul, Yogyakarta 55183

Telepon : (0274) 387656 Ext. 346

Email : jphk@umy.ac.id

\title{
Dampak Kerusakan Lingkungan Akibat Penambangan Pasir Merapi di Klaten
}

Arief K. Syaifulloh

Magister Hukum, Universitas Muhammadiyah Yogyakarta, Indonesia

E-mail: dematadewa@gmail.com

\author{
INFO ARTIKEL \\ Perjalanan Artikel: \\ Artikel Dikirimkan oleh \\ penulis: 09-10-20 \\ Artikel Direview: 24-05-20 \\ Artikel Direvisi: 10-11-21 \\ Artikel Diterima atau \\ Dipublikasikan: 16-11-21 \\ DOI: \\ 10.18196/jphk.v2i2.9990
}

\begin{abstract}
ABSTRAK
Penelitian yuridis empiris ini dilakukan untuk mengkaji dampak kerusakan lingkungan akibat penambangan pasir Merapi di Klaten. Amanah konstitusi menegaskan bahwa bumi, air, dan kekayaan alam yang terkandung di dalamnya dikuasai oleh negara dan dipergunakan untuk sebesar-besar kemakmuran rakyat. Hasil penelitian diperoleh bahwa penambangan pasir merapi di Klaten Jawa Tengah memiliki beberapa dampak. Pertama, penambangan berdampak pada rusaknya lahan pertanian dan lahan perkebunan. Rusaknya lahan ini mengancam ketersediaan lahan bagi generasi petani yang akan datang dan tentu akan berpengaruh pada ketersediaan pangan. Dampak kedua yang diakibatkan penambangan yaitu merusak jalur evakuasi dan yang ketiga yaitu mengganggu resapan air, ekologi, serta rawan longsor.
\end{abstract}

Kata Kunci: Gunung Merapi, kerusakan lingkungan, penambangan pasir

\section{Pendahuluan}

Pasal 33 ayat (3) UUD 1945 menyatakan bahwa bumi, air dan kekayaan alam yang terkandung di dalamnya dikuasai oleh negara, itu mengkonfirmas sejahterakan rakyat sebesar-besarnya. Sumber daya alam bumi seperti mineral dan batubara, merupakan sumber daya alam yang tidak dapat diperbaharui, sehingga harus dikelola secara optimal guna mencapai manfaat dan kesejahteraan yang sebesar-besarnya bagi rakyat. Selanjutnya pembangunan pertambangan harus beradaptasi dengan perubahan lingkungan strategis, baik secara nasional maupun internasional. Tantangan utama bagi industri pertambangan dan batubara adalah dampak globalisasi yang mendorong demokratisasi, otonomi daerah, hak asasi manusia, lingkungan hidup, perkembangan teknologi dan informasi, hak kekayaan intelektual dan yang disebut dengan peran yang lebih kuat bagi sektor swasta, dan masyarakat.

Pasokan energi Indonesia masih menghadapi kendala yang cukup berarti karena peningkatan konsumsi yang jauh lebih cepat dibandingkan dengan peningkatan pasokan energi. Peningkatan konsumsi tersebut sangat didorong oleh peningkatan 
pertumbuhan ekonomi, yang meningkatkan permintaan energi di sektor komersial dan industri, serta peningkatan konsumsi di tingkat rumah tangga. ${ }^{1}$

Indonesia merupakan negara yang memiliki potensi kekayaan alam yang sangat besar. Potensi kekayaan alam tersebut berupa sumberdaya yang dapat diperbaharui maupun yang tidak dapat diperbaharui. Kekayaan alam yang tidak dapat diperbaharui adalah minyak bumi, gas alam, batubara, barang tambang dan mineral lainnya yang memberikan kontribusi yang cukup besar pada perekonomian Indonesia Sumberdaya alam di Indonesia cukup melimpah sehingga dieksploitasi secara besarbesaran untuk kebutuhan pembangunan. Pertambangan artinya salah satu upaya untuk memanfaatkan sumberdaya alam dengan melakukan suatu aktivitas mulai dari pencarian, penggalian, pengolahan sampai dengan pemasaran hasil tambang. ${ }^{2}$

Rangkaian aktivitas pertambangan selalu bersinggungan dengan lingkungan hidup. Lingkungan merupakan wadah untuk berinteraksinya makhluk hidup yang berada didalamnya untuk menghasilkan jaringan kehidupan. ${ }^{3}$ Pada pengelolaan lingkungan, diperlukan prinsip berkelanjutan demi kelestarian lingkungan. Pengelolaan lingkungan yang baik sebagai wujud usaha pembangunan jangka panjang untuk kesejahteraan hidup. ${ }^{4}$

Undang-undang tentang Pertambangan Mineral dan Batubara (selanjutnya ditulis dengan Undang-Undang Minerba) menyatakan bahwa aktivitas usaha pertambangan mineral dan batubara adalah aktivitas usaha pertambangan pada luar panas bumi, minyak dan gas bumi dan air tanah memiliki peranan krusial untuk memberikan nilai tambah secara konkret pada pertumbuhan ekonomi nasional dan pembangunan daerah secara berkelanjutan. ${ }^{5}$ Lebih lanjut Pasal 2 Undang-Undang Minerba bahwa terdapat 4 asas pengelolaan pertambangan mineral dan/atau batubara di Indonesia, yaitu: “(1) Asas manfaat, keadilan, dan keseimbangan; (2) Asas keberpihakan kepada kepentingan bangsa; (3) Asas partisipatif, transparansi, dan akuntabilitas; dan (4) Asas berkelanjutan dan berwawasan lingkungan.

Fakta di Indonesia, sebagian besar pertambangan dilakukan dengan sistem tambang terbuka (open pit mining), yang berakibat pada kerusakan lingkungan. Dampak kerusakan lingkungan antara lain hilangnya vegetasi hutan, tumbuhan dan hewan, serta lapisan tanah. Hal ini menyebabkan terganggunya fungsi hidrologis, keragaman jenis (biodiversity), serapan karbon, pemasok oksigen dan pengatur suhu

1 Deputi Sumber Daya Alam dan Lingkungan Hidup. (2014). Prakarsa Strategis Pengembangan Konsep Green Economy (Endah Murniningtyas, ed.). Jakarta: Kementerian Perencanaan Pembangunan Nasional/Bappenas. Hlm. 75

2 Irawan P. (2006). Penelitian Kualitatif \& Kuantitatif untuk Ilmu-Ilmu Sosial. DIA Fisip UI, Jakarta. Hlm. 1

3 Uar, N. D., Murti, S. H., \& Hadisusanto, S. (2016). Kerusakan Lingkungan Akibat Aktivitas Manusia pada Ekosistem Terumbu Karang. Majalah Geografi Indonesia, 30(1), 88-95. https://doi.org/10.22146/mgi.15626. Hlm. 89

4 Riskanita, D., \& Widowaty, Y. (2019). Upaya Pemerintah Daerah Mengatasi Kerusakan Lingkungan Akibat Alih Fungsi Lahan Berdasarkan Konsep Negara Kesejahteraan. Supremasi Hukum: Jurnal Penelitian Hukum, 28(2), 123-134. https://doi.org/10.33369/jsh.28.2.123-135. Hlm. 125

5 Undang-undang Nomor 4 Tahun 2009 Tentang Pertambangan Mineral dan Batubara 
lingkungan. Di samping juga akan menyebabkan perubahan pada Daerah Aliran Sungai (DAS) seperti: berkurangnya debit air sungai, rusaknya bentang lahan sebagai recharge area, tingginya sedimentasi, menurunnya kualitas air sungai dan infiltrasi. ${ }^{6}$ Dampak tersebut juga terjadi di daerah penambangan pasir di Kabupetan Klaten Jawa Tengah. Selain itu, penambangan tersebut dilakukan di atas lahan pertanian, sehingga dalam jangka panjang akan mengancam ketersediaan lahan bagi petani, yang nantinya akan berakibat pada ketersediaan kebutuhan pangan.

Usaha perambangan di Klaten Sebagian besar menggunakan alat berat dan ada dugaan bahwa usaha-usaha tambang tersebut tidak berizin. Pada akhir tahun 2019, Kepala Desa setempat menyetujui sekitar 40 izin baru yang dikeluarkan atau direkomendasikan. ${ }^{7}$ Izin-izin usaha ini apabila disetujui tanpa ada pemahaman ekosistem, baik bagi masyarakat, pelaku pertambangan maupun pihak terkait, maka hal ini akan berdampak pada kerusakan lingkungan. Letak lokasi wilayah pertambangan jauh dari penduduk dan tidak mudah dijangkau, hal itu menyebabkan wilayah pertambangan tidak mudah untuk dipantau, bahkan pada masa Pandemi Covid-19, para penambang tetap melakukan aktivitas pertambangan terus-menerus. ${ }^{8}$

Aktivitas pertambangan ini, dikhawatirkan akan berdampak buruk bagi rusaknya jalur evakuasi, serta ancaman bencana alam seperti tanah longsor dan banjir. Para pelaku usaha tambang juga meninggalkan bekas-bekas galian berlubang di lokasi pertambangan, tanpa melakukan upaya reklamasi. Pemandangan hijau Kawasan Kemalang yang merupakan daerah resapan air, saat ini semakin habis dikeruk oleh alat-alat berat penambang.

Sebenarnya Gunung Merapi kehadirannya memberikan dampak positif dan dampak negatif bagi masyarakat sekitar Kawasan Gunung Merapi. Gunung Merapi adalah gunung teraktif di Indonesia yang setiap 2 hingga 15 tahun selalu mengeluarkan material vulkanik. Setiap semburan material vulkanik Gunung Merapi yang mengalir ke 13 sungai yang berada di Gunung Merapi, selain menyebabkan bencana bagi masyarakat juga memberikan dampak positif bagi masyarakat di sekitar kawasan Gunung Merapi. Semburan material vulkanik dimanfaatkan warga untuk pertambangan bahan galian Karbon (C) yang secara ekonomi memberikan pendapatan bagi masyarakat sekitar. Bukan hanya itu, bahkan perekonomian masyarakat sekitar menjadi stabil dan meningkat. ${ }^{9}$

6 Irawan P. (2018). Loc. Cit

7 Prakoso, T. S. (2015). Penambangan Pasir Klaten: Belasan Usaha Penambangan Diduga Ilegal. Solopos.com. Diakses pada 21 Juni 2020, dikutip dari https://www.solopos.com/penambangan-pasirklaten-belasan-usaha-penambangan-diduga-ilegal-661001

8 Wakik, A. K. (2020). Manfaatkan Pandemik Covid-19, Penambang Pasir Ilegal Di Klaten Diam-diam Beroperasi. Republik Merdeka. Diakses pada 21 Juni 2020, dikutip dari https://nusantara.rmol.id/read/2020/05/05/433486/manfaatkan-pandemik-covid-19 penambang-pasirilegal-di-klaten-diam-diam-beroperasi.

9 Yudhistira, Y., Hidayat, W. K., \& Hadiyarto, A. (2012). Kajian Dampak Kerusakan Lingkungan Akibat Kegiatan Penambangan Pasir Di Desa Keningar Daerah Kawasan Gunung Merapi. Jurnal Ilmu Lingkungan, 9(2), 76-84. https://doi.org/10.14710/jil.9.2.76-84 
Mayoritas masyarakat sekitar Gunung Merapi bermata pencaharian sebagai penambang pasir tradisonal, walaupun terdapat Sebagian yang sudah menggunakan peralatan modern. Penambang pasir tradisional dilakukan oleh masyarakat sebelum tahun 1992. Masyarakat secara berkelompok mengumpulkan pasir di suatu titik. Penambangan pasir modern dilakukan sejak tahun 1992 dengan menggunakan alat berat seperti Wheel Loader dan Excavator. Akantetapi sampai saat ini, masyarakat asli sekitar Gunung Merapi masih melakukan penambangan pasir secara tradisional, sementara investor atau perusahaan penambang asing melakukan penambangan pasir secara modern. Selama ini, perusahaan penambang asing bekerjasama dengan beberapa masyarakat sekitar kawasan Gunung Merapi baik yang terdapat di wilayah Propinsi Jawa Tengah maupun Propinsi Yogyakarta dalam melakukan penambangan. Sampai saat ini sudah terdapat ratusan perusahaan penambang yang memperoleh izin pertambangan pasir di kawasan hulu Sungai Merapi. ${ }^{10}$

Di era otonomi daerah ini, pemerintah daerah diberi kewenangan untuk mengelola sumber daya daerah untuk meningkatkan pendapatan asli daerah melalui pemberian izin kepada perusahaan penambang pasir untuk beroperasi di kawasan gunung Merapi. Dengan demikian Pemerintah daerah dapat mengelola pendapatan dari pemanfaatan sumber daya alam daerah. Perusahaan penambang modern menguasai penambangan pasir di Gunung Merapi. Pemberian izin penambangan kepada perusahaan penambang pasir modern berdampak pada peningkatan pendapatan asli daerah dari bahan galian (C). ${ }^{11}$

Melihat fakta yang ada, serta bagaimana Undang-undang mengatur maka disinilah pemahaman terhadap ekosistem sangat penting dalam upaya pengelolaan lingkungan hidup. Pertimbangan sosial juga sangat erat kaitannya dengan proses politik dan pengambilan keputusan dalam pengembangan pengetahuan lingkungan hidup ${ }^{12}$. Sesuai Perpres Nomor 70 tahun 2014 Tentang Rencana Tata Ruang Kawasan Taman Nasional Gunung Merapi, kawasan lereng Merapi wilayah Kemalang termasuk dalam zona lindung, hortikultura dan perkebunan. ${ }^{13}$

Perpres Nomor 70 tahun 2014 tersebut menunjukkan secara detail dan jelas betapa sebenarnya realitas wilayah Kabupaten Klaten yang berada pada Zona Budi Daya lebih dominan daripada zona wilayah pertambangan. Sejak tahun 2019 izin pertambangan di Kabupaten Klaten sudah tidak dikeluarkan. Izin pertambangan yang dikeluarkan beralih kepada pemberian izin bentuk kegiatan lain dalam bidang

\footnotetext{
10 Widyastomo, B., \& Risyanto. (2013). Pengaruh Penambangan Pasir dan Batu Terhadap Kondisi Sosial Ekonomi Penambang di Kecamatan Kemalang Kabupaten Klaten, Provinsi Jawa Tengah. Jurnal Bumi Indonesia, 2(3), 270-276.

11 Aisyah, N., \& Purnamawati, D. I. (2012). Tinjauan Dampak Banjir Lahar Kali Putih Kabupaten Magelang Pasca Erupsi Merapi 2010. Jurnal Teknologi Technoscientia, 5(1), 19-30. Hlm. 19-28.

12 Patiung dkk dalam Willyam Buli, 2018, Strategi Pengendalian Kerusakan Lingkungan Melalui Pembenahan Kelembagaan Pertambangan Batubara Tanpa Ijin Studi Kasus Di Kabupaten Muara Enim, Program Pascasarjana Universitas Lampung, Bandar Lampung. Hlm. 1.

13 Aditya, I. (2020). Penambangan Pasir Rusak Ekosistem Lereng Merapi. krjogja.com. Diakses pada 21 Juni 2020, dikutip dari https://www.krjogja.com/berita-lokal/jateng/klaten/penambangan-pasir-rusakekosistem-lereng-merapi/.
} 
penataan lahan bekas sisa tambang ilegal yang ditinggalkan dan penataan perkebunan sebagaimana yang terjadi selama ini. ${ }^{14}$ Sejak Pemerintah Daerah Kabupaten Klaten mengeluarkan izin perkebunan, sampai saat ini tercatat ada belasan perusahaan yang mengantongi izin perkebunan, sementara perusahan penambangan pasir yang masih memiliki izin penambangan pasir masih ada 7 (tujuh). Berdasarkan latar belakang tersebut, maka pada penelitian ini, penulis meneliti tentang bagaimana Dampak Kerusakan Lingkungan Akibat Penambangan Pasir Merapi di Klaten.

\section{Metodologi}

Metode penelitian yuridis empiris digunakan untuk mengakaji gejala-gejala dan akibat yang terjadi di lapangan. Penelitian ini menggunakan metode observasi untuk melihat bagaimana berjalannya hukum (law in action) ${ }^{15}$. Penulis melakukan pengumpulan data dengan teknik Wawancara (interview), sdlam penelitian ini melakukan wawancara langsung dengan narasumber di lokasi penelitian dan dinas terkait serta pakar tentang Hukum Lingkungan. Data disusun secara sistematis, selanjutnya dianalisis dengan menggunakan metode analisis kualitatif. Penarikan kesimpulan penelitian mempergunakan cara berpikir induktif. ${ }^{16}$

\section{Analisis dan Hasil}

\subsection{Gambaran Umum Kondisi Daerah Kabupaten Klaten}

Pemerintah Provinsi Jawa Tengah memiliki 35 kabupaten/kota, dan salah satunya Kabupaten Klaten. Kabupaten Klaten selama ini mempunyai nilai strategis dan memiliki peran yang sangat penting dalam proses pertumbuhan wilayah di Jawa Tengah. Wilayah Kabupaten Klaten berada pada jalur strategis, karena berbatasan langsung dengan Provinsi Daerah Istimewa Yogyakarta. Kabupaten Klaten terletak antara $7^{\circ} 32{ }^{\prime} 19^{\prime \prime}$ Lintang Selatan sampai $7^{\circ} 48^{\prime} 33^{\prime \prime}$ Lintang Selatan dan antara $110^{\circ} 26^{\prime} 14^{\prime \prime}$ Bujur Timur sampai $110^{\circ} 47^{\prime} 51^{\prime \prime}$ Bujur Timur dari bentangan Khatulistiwa.

Kondisi topografi wilayah Kabupaten Klaten diapit oleh Gunung Merapi dan Pegunungan Seribu, dengan ketinggian antara 76-1.600 mdpl (di atas permukaan laut). Secara geografis terbagi ke dalam 3 (tiga) wilayah, yaitu:

a. Wilayah lereng Gunung Merapi (wilayah bagian utara) yang meliputi Kecamatan Karangnongko, Kemalang, Jatinom dan Tulung.

b. Wilayah datar (wilayah bagian tengah) yang meliputi wilayah kecamatan Manisrenggo, Klaten Tengah, Kalikotes, Klaten Utara, Klaten Selatan, Ngawen,

\footnotetext{
14 Wawancara langsung dengan Kepala Dinas Lingkungan Hidup dan Kehutana Kabupaten Klaten SRI HADIE

15 Riskanita, D., \& Widowaty, Y. (2019). Upaya Pemerintah Daerah Mengatasi Kerusakan Lingkungan Akibat Alih Fungsi Lahan Berdasarkan Konsep Negara Kesejahteraan. Supremasi Hukum: Jurnal Penelitian Hukum, 28(2), 123-134. https:/ / doi.org/10.33369/jsh.28.2.123-135. Hlm. 125.

16 Hamidi. (2004). Metode Penelitian Kualitatif. Malang: UMM Press. Hlm. 251.
} 
Kebonarum, Wedi, Jogonalan, Prambanan, Gantiwarno, Delanggu, Wonosari, Juwiring, Ceper, Pedan, Karangdowo, Trucuk, Cawas, Karanganom, Polanharjo.

c. Wilayah berbukit/ gunung kapur (wilayah bagian selatan) yang hanya meliputi sebagian Kecamatan Bayat, Cawas dan Gantiwarno.

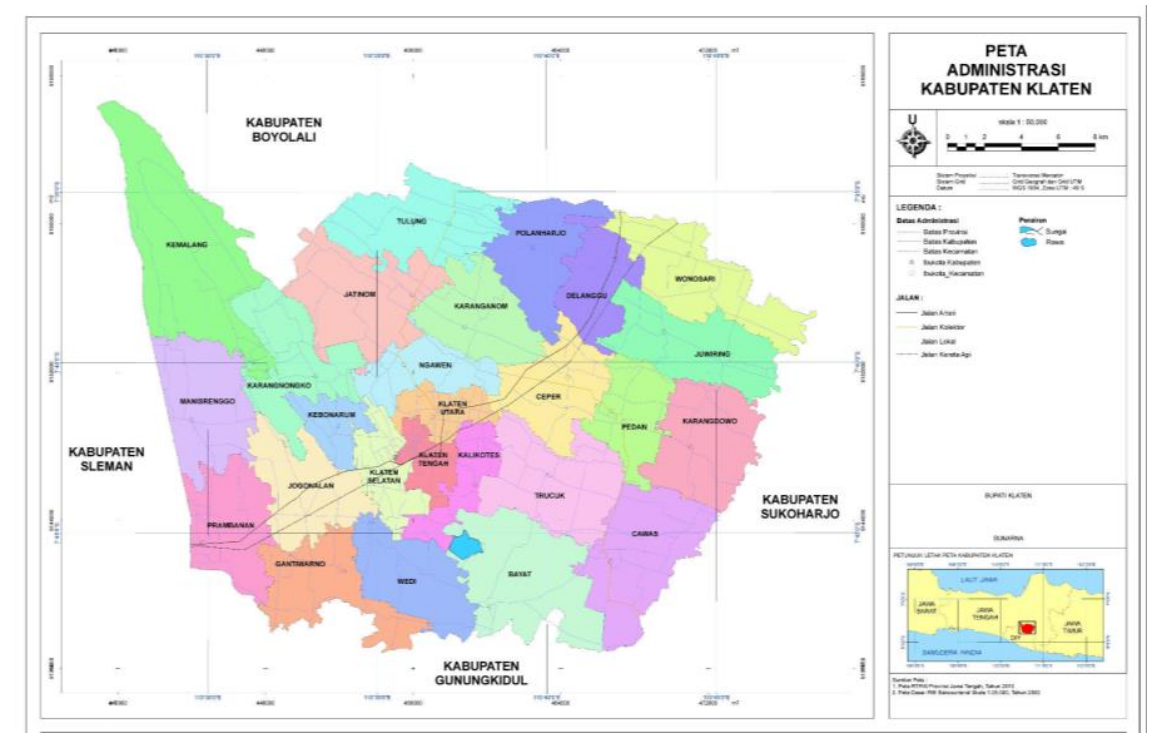

Gambar 1. Peta Wilayah Kabupaten Klaten berdasarkan kecamatan Sumber : Data RTRW Kabupaten Klaten 2009-2021

\subsection{Dampak Lingkungan Akibat Penambangan Pasir Merapi di Klaten}

Sepanjang sejarah, pada satu sisi pertambangan merupakan sektor yang menyediakan sumber energi dan materi penting untuk kemajuan umat manusia. Sementara disisi lain, pertambangan juga dikenal sebagai sektor yang menghadirkan banyak sekali masalah bagi lingkungan dan masyarakat yang hidup di sekitar daerah tambang.

Lokasi pertambangan selalu ditemukan di daerah terpencil yang bersebelahan dan bersinggungan dengan kawasan sensitif ekologi lain yang ditempati oleh masyarakat tradisional. Hal ini harus dikelola dengan benar sehingga tidak menimbulkan kerusakan ekositem dan kerusakan lingkungan khususnya wilayah pemukiman. Harapannya, selain menjaga kelestarian lingkungan, pertambangan juga memberikan manfaat secara sosial dan meningkatkan ekonomi masyarakat sebagai peluang bisnis dengan membuka lapangan kerja, pembangunan infrastruktur dan pemasukan bagi pendapatan asli daeran serta nasional dari sektor fiskal.

Pengelolaan pertambangan yang tidak benar akan menimbulkan kerusakan lingkungan. Lubang-lubang bekas tambang dengan air asamnya merupakan kerugian yang nyata bagi lingkungan. Penggusuran penduduk secara paksa, serta konflik dengan masyarakat adalah dampak pertambangan yang banyak dilaporkan. Demikian juga, kekayaan dari pertambangan yang seharusnya bisa dinikmati oleh negara dan warganya, banyak yang hilang lantaran korupsi. 
Kinerja buruk pertambangan dalam pengelolaan lingkungan, sosial dan ekonomi dapat disimak dengan jelas di film Sexy Killers yang menggambarkan sisi buruk pertambangan batubara yang sudah lama diketahui secara luas. Dalam dunia yang sedang berhadapan dengan perubahan iklim, tambang dan pembangkit listrik tenaga batubara memang tidak popular. ${ }^{17}$

Kondisi lingkungan yang rusak parah akibat kegiatan pertambangan terjadi di daerah Kemalang, Klaten. Kondisi jalan, pemukiman dan lahan bisa dikatakan rusak parah akibat kegiatan pertambangan batuan dan pasir yang terus menerus dieksploitasi secara besar-besaran oleh pengusaha yang berbadan hukum maupun oleh warga masyarakat secara ilegal.18

Kegiatan penambangan pasir di daerah Kemalang telah menimbulkan dampak fisik lingkungan dan dampak sosial ekonomi. Terkait dengan dampak penambangan terhadap sebuah kawasan juga pernah diteliti oleh Yudhistira di Desa Keningar. Dari penelitian tersebut, Yudistira mengidentifikasi dampak fisik lingkungan dan dampak sosial ekonomi. Adapun dampak fisik lingkungan adalah sebagai berikut: ${ }^{19}$ (1) tingginya tingkat erosi di daerah penambangan pasir dan juga didaerah sekitarnya; (2) adanya tebing-tebing bukit yang rawan longsor karena penambangan yang tidak memakai sistem berteras sehinggaa sudut lereng menjadi terjal dan mudah longsor; (3) berkurangnya debit air permukaan/mata air; (4) tingginya lalu lintas kendaraan di jalan desa membuat mudah rusaknya jalan; dan (5) terjadinya polusi udara.

Sementara dampak sosial ekonomi akibat kegiatan penambangan pasir antara lain: (1) pengurangan jumlah pengangguran karena sebagian masyarakat bekerja menjadi tenaga kerja di penambangan pasir, baik sebagai pengawas, buruh tambang, penjual makanan dan minuman; (2) adanya pemasukan bagi pemilik tanah yang dijual atau disewakan untuk diambil pasirnya dengan harga tinggi. Tanah yang semula tidak menghasilkan menjadi bermanfaat karena dipakai untuk penambangan pasir; (3) banyaknya pendatang yang ikut menambang sehingga dapat menimbulkan konflik; dan adanya ketakutan sebagian masyarakat karena penambangan pasir yang berpotensi longsor sehingga sewaktu-waktu bisa mengenai lahan dan pemukiman mereka, apalagi bila turun hujan. ${ }^{20}$

Adanya kesempatan atau peluang yang bisa dinikmati secara ekonomi oleh warga sekitar pertambangan membuka peluang untuk melakukan perbuatan penambangan secara liar tanpa izin karena menurut keterangan warga sekitar, selama

17 Jalal. (2019). Sexy Killers: Pertambangan dan/atau Pembangunan Berkelanjutan? Mongabay: Situs Berita Lingkungan. Diakses 18 Juli 2020, dikutip dari https://www.mongabay.co.id/2019/05/02/sexykiller-pertambangan-dan-atau-pembangunan-berkelanjutan-1/

18 Wawancara dengan Bowo Hariyono warga Dompyongan yang terkena dampak penambangan pasir Merapi

${ }^{19}$ Yudhistira, Y., Hidayat, W. K., \& Hadiyarto, A. (2012). Kajian Dampak Kerusakan Lingkungan Akibat Kegiatan Penambangan Pasir Di Desa Keningar Daerah Kawasan Gunung Merapi. Jurnal Ilmu Lingkungan, 9(2), 76-84. https://doi.org/10.14710/jil.9.2.76-84

20 Ibid, 
ada pertambangan dampak kerusakan lingkungan dan pencemaran udara setiap hari dirasakan oleh warga sehingga hal tersebut membuat warga yang tidak memiliki izin juga ikut melakukan kegiatan penambangan. Dikatakan bahwa warga sekitar tambang juga ingin turut menikmati hasil dari lingkungan mereka yang dieksploitasi. Akibat penambangan pasir tersebut sudah banyak terjadi kerusakan lahan dan jalan yang mengabaikan kepentingan warga sekitar tambang terkena dampak debu setiap hari secara terus-menerus.

Perusahan penambangan pasir yang menggunakan alat berat di Klaten diduga tidak berizin atau bisa dikatakan sebagai penambang illegal. Pada tahun 2019 Kepala Desa setempat merekomendasikan 40 (empat puluh) perusahaan penambang untuk diberikan izin pertambangan. ${ }^{21}$

Izin-izin tersebut adalah bentuk izin kegiatan lain berupa penataan perkebunan yang antara lain adalah:

a. Izin Informasi Tata Ruang (ITR) dari Badan Pertanahan Nasional (BPN) untuk mengetahui kepastian hukum mengenai zona wilayah yang akan digunakan untuk melakukan kegiatan pertambangan;

b. Izin dari Dinas Pertanian untuk kegiatan penataan perkebunan;

c. Izin dari Dinas Lingkungan Hidup dan Kehutanan berupa Upaya Pengelolaan Lingkungan (UKL) dan Upaya Pemantauan Lingkungan (UPL);

d. Izin dari Kementrian ESDM Provinsi untuk mendapatkan Izin Usaha Pertambangan Operasi Produksi (IUP OP) Khusus Pengangkutan dan Penjualan.

Izin kegiatan lain berupa penataan perkebunan dikeluarkan dengan tujuan untuk mengrangi dampak buruk penambangan pasir. Hal ini dilatar belakangi bahwa selama ini upaya reklamasi sangat minin atau bahkan tanpa reklamasi pada bekasbekas lokasi penambangan. ${ }^{22}$ Walaupun hanya mendapatkan izin berkegiatan lain dengan penataan perkebunan atau budidaya perkebunan, akan tetapi para penambang pasir ini ternyata tetap melakukan kegiatan pertambangan batuan dan pasir di wilayah lereng gunung Merapi Klaten. Jika saat ini ditemukan bentuk kegiatan lain, seperti penataan perkebunan, itupun yang ini hanya dilakukan dengan asal-asalan sehingga target utama daripada terbentuknya lahan perkebunan untuk kesejahteraan rakyat tidak tercapai. ${ }^{23}$

Izin usaha perkebunan berbeda dari izin penataan lahan yang sebelumnya pernah dikeluarkan di Kabupaten Klaten. Ijin penataan lahan hanya memerlukan izin lingkungan dari Dinas Lingkungan Hidup dan Kehutanan, Dinas ESDM provinsi dan izin usaha. Namun izin usaha perkebunan harus ada izin usaha dan izin lokasi dari Badan Pertanahan Nasional. Rekomendasi atau izin dari Badan Pertanahan Nasional

21 https://m.solopos.com/penambangan-pasir-klaten-belasan-usaha-penambangan-diduga-ilegal661001 Akses pada tanggal 21 Juni 2020, pukul 13.05 Wib

${ }^{22}$ Aditya, I. (2020). Penambangan Pasir Rusak Ekosistem Lereng Merapi. krjogja.com. Diakses pada 21 Juni 2020, dikutip dari https://www.krjogja.com/berita-lokal/jateng/klaten/penambangan-pasir-rusakekosistem-lereng-merapi/.

23 Wawancara dengan warga masyarakat di Kemalang Klaten 
tersebut dikeluarkan karena pada penataan perkebunan yang lahannya menggunakan tanah warga harus melakukan verifikasi dari Badan Pertanahan Nasional agar lahan yang digunakan tersebut benar-benar dinyatakan tidak dalam keadaan bersengketa.

Apabila dalam kegiatan izin perkebunan itu ternyata harus menata lahan bekas tambang dan harus mengeluarkan material, pengusaha harus memiliki izin lingkungan dan mencari Izin Usaha Pertambangan Khusus (IUPK) ke Dinas ESDM Provinsi. Kebijakan izin usaha perkebunan itu diberlakukan dengan dasar Peraturan Menteri Pertanian No 29 /2016 tentang Perubahan Atas Permentan No 98/2013 tentang Perijinan Usaha Perkebunan.

Dinas Lingkungan Hidup berperan dalam menerbitkan dokumen Upaya Pengelolaan Lingkungan Hidup (UKL) dan Upaya Pemantauan Lingkungan Hidup (UPL). Dokumen itu sebagai dasar terbitnya izin lingkungan. Dengan kebijakan baru tersebut, masyarakat diminta memahami sehingga tidak ada lagi lahan yang dikeruk dan ditata semata tetapi ada usaha perkebunannya. Selain itu, dengan izin perkebunan, masyarakat sekitar dan elemen lain bisa mengontrol lantaran dalam izin perkebunan terdapat aturan menanam komoditas tertentu. Jika tidak ditanami, maka warga bisa melaporkan ke Pemerintah Kabupaten (Pemkab).

Sementara dengan kemudahan izin melakukan kegiatan lain dalam bentuk penataan perkebunan, saat ini hal tersebut tetap menimbulkan masalah baru yang ditemukan dilapangan.Kegiatan lain yang dimaksud dalam bentuk penataan perkebunan tersebut pada prinsipnya adalah kegiatan penambangan pasir. Sebelum dilakukan penataan perkebunan, lahan yang diizinkan tersebut terlebih dahulu dikeluarkan material berupa pasir dan batuannya, disinilah potensi ekonomi yang menjadi tujuan utama para pelaku kegiatan penataan perkebunan yang terjadi di Kabupaten Klaten.

Dari hasil wawancara dengan narasumber dilapangan ditemukan beberapa hal yang menjadi permasalahan mendasar terkait dengan bentuk kegiatan lain penataan perkebunan di wilayah kabupaten Klaten, antara lain sebagai berikut24:

a. Bahwa dengan mudahnya mendapatkan izin penataan perkebunan di wilayah kabupaten Klaten, para pelaku usaha pertambangan lebih memilih melakukan pengurusan izin penataan perkebunan tersebut daripada mengurus izin pertambangan yang harus sampai di kementerian ESDM;

b. Izin bentuk kegiatan lain penataan perkebunan lebih murah daripada mengurus izin pertambangan;

c. Karena tujuan dari kegiatan penataan perkebunan tersebut adalah mengeluarkan material batuan dan pasir yang ada di lokasi perkebunan yang telah diizinkan, prioritas pekerjaan yang dilakukan tetap pada pengeluaran material tersebut bukan pada penataan perkebunannya sehingga banyak ditemukan lahan yang ditinggalkan atau lahan dengan tanaman yang asal-asalan;

${ }^{24}$ Kompilasi wawancara dengan Kepala Dinas Lingkungan Hidup Dan Kehutanan Kabupaten Klaten "Sri Hadi", Warga Kemalang Klaten, Sopir, dan Pengelola Pertambangan 
d. Karena prioritas kegiatan penataan perkebunan tersebut mengeluarkan material batuan dan pasir, maka pada saat tidak terdapat material batuan dan pasir yang bagus, lahan hanya ditinggalkan begitu saja walaupun telah berizin. Pengusaha lebih memilih pindah tempat dengan mengurus izin baru lagi karena perizinan bentuk kegiatan lain penataan perkebunan lebih murah dan mudah;

e. Karena prioritas utama daripada ijin bentuk kegiatan lain penataan lahan perkebunan adalah mengeluarkan material batuan dan pasir ditemukan pengusaha yang melakukan perluasan lahan yang diizinkan untuk mengeluarkan material batuan dan pasir di luar yang telah diberikan izin;

f. Karena prioritas utama dari bentuk kegiatan lain penataan perkebunan adalah mengeluarkan material batuan dan pasir dalam melakukan kegiatan penataan lahan perkebunan sering melanggar ketentuan yang terdapat di dalam IUP OP misalnya:

1) Melanggar batas waktu yang ditentukan untuk melakukan aktivitas pekerjaan atau jam operasional;

2) Melanggar jumlah alat berat yang dipergunakan untuk mengeluarkan batuan dan pasir;

3) Melanggar ketentuan kedalaman galian untuk mengeluarkan material batuan dan pasir;

4) Melanggar jumlah Stockfill (Satuan Jumlah Material batuan dan pasir yang boleh dikeluarkan) yang ditentukan;

5) Melanggar aturan mengeruk pada tebing untuk mengeluarkan material batuan dan pasir;

6) Melanggar ketentuan pelaksana operasional yang diharuskan mempunyai keahlian khusus dan bersertifikat;

7) Melanggar titik koordinat peta yang diizinkan;

8) Masih banyak lagi ditemukan pelanggaran-pelanggaran yang dilakukan oleh pengusaha karena tujuan utamanya adalah mengambil keuntungan yang sebesar-besarnya dengan mengeluarkan material berupa batuan dan pasir.

Sejak lahirnya Undang-undang nomor 3 tahun 2020 peran Pemerintah Daerah dihilangkan dan kewenangan pengelolaan pertambangan mineral dan batubara diambil oleh pemerintah pusat melalui Kementerian ESDM sebagaimana dapat dilihat pada pasal 8 yang dihapus dan diganti dengan pasal 8A. Kewenangan pemerintah daerah yang wajib melakukan penyelidikan dan penelitian pertambangan dalam rangka menyiapkan WP Wilayah Pertambangan juga ditarik menjadi kekuasaan menteri di pemerintahan pusat dapat dilihat pada pasal 11.

Kita temukan di dalam pasal 14 Undang-Undang Nomor 4 Tahun 2009 juga dihapus pada Undang-Undang Nomor 3 Tahun 2020 yang artinya bahwa seluruh kekuasaan pemerintah daerah telah dikooptasi dan ditarik menjadi kekuasaan pemerintah pusat. Padahal hal tersebut berkaitan dengan penetapan wilayah usaha pertambangan atau WUP di mana pemerintah daerah memiliki wilayah tersebut dan secara teknis lebih mengetahui dan menguasai daerah sebagaimana akan ditetapkan sebagai WP.

Konsepsi dalam misi Rencana Pembangunan Jangka Menengah Daerah (RPJMD) Pemerintah Daerah Kabupaten Klaten saat ini adalah dengan terbitnya Perda RTRT. 
Namun terkait dengan kebijakan dalam bidang pertambangan belum dirumuskan sebagai misi dari RPJMD karena dalam rumusan tersebut masih menyampaikan bahawa permasalahan penegakan hukum dalam bidang pertambangan dan lingkungan belum diberikan solusi dalam bentuk kegiatan yang harus dilakukan atau produk yang harus dibuat.

Dari uraian diatas dapat diberikan catatan untuk dirumuskan menjadi kebijakan yang ideal yang bisa digunakan di Kabupaten Klaten khususnya dalam menjaga kerusakan lingkungan yang terjadi selama ini akibat pertambangan batuan dan pasir di kawasan Merapi antara lain sebagai berikut :

a. Penataan Perkebunan atau Budidaya Perkebunan merupakan izin kegiatan lain yang diajukan untuk kegiatan pertambangan dengan mengeluarkan batuan dan pasir dari wilayah perkebunan yang diizinkan;

b. Dalam pasal 2 Peraturan Menteri Pertanian Republik Indonesia Nomor 98/Permentan/Ot.140/9/2013 Tentang Pedoman Perijinan Usaha Perkebunan disebutkan bahwa peraturan ini dimaksudkan sebagai dasar hukum dalam pemberian pelayanan perijinan dan pelaksanaan kegiatan usaha perkebunan, dengan tujuan untuk memberikan perlindungan, pemberdayaan pelaku usaha perkebunan secara berkeadilan dan memberikan kepastian dalam usaha perkebunan;

c. Pembinaan dan pengawasan terhadap perijinan usaha perkebunan dapat dilihat pada Pasal 44 dimana pada Ayat 1 menyatakan bahwa pembinaan dan pengawasan terhadap pelaksanaan perijinan usaha perkebunan dilakukan oleh direktorat jenderal gubernur dan Bupati atau walikota sesuai kewenangannya hal ini merupakan pintu masuk bagi Bupati untuk ikut melakukan pembinaan dan pengawasan secara lebih maksimal;

d. Dalam Pasal 13 Undang-undang Nomor 32 Tahun 2009 Tentang Perlindungan dan Pengelolaan Lingkungan Hidup dijelaskan sebagai berikut bahwa: (1) Pengendalian pencemaran dan/atau kerusakan lingkungan hidup dilaksanakan dalam rangka pelestarian fungsi lingkungan hidup; (2) Pengendalian pencemaran dan/atau kerusakan lingkungan hidup sebagaimana dimaksud pada Ayat (1) meliputi: Pencegahan; Penanggulangan; dan Pemulihan; (3) Pengendalian pencemaran dan/atau kerusakan lingkungan hidup sebagaimana dimaksud pada Ayat (1) dilaksanakan oleh Pemerintah, pemerintah daerah, dan penanggung jawab usaha dan/atau kegiatan sesuai dengan kewenangan, peran, dan tanggung jawab masingmasing. Saat ini tidak maksimal dilakukan karena hanya Dinas Lingkungan Hidup dan Kehutanan (DLHK) yang berfungsi melakukan Pengawasan dan Evaluasi setelah 6 bulan".

e. Tentang Izin Lingkungan dalam Undang-undang Nomor 32 Tahun 2009 Tentang Perlindungan dan Pengelolaan Lingkungan Hidup diatur dalam pasal 36 sampai dengan pasal 41 dimana Pemerintah Daerah diberikan kewenangan untuk 
memberikan izin UKL UPL dan Analisin Mengenai Dampak Lingkungan (AMDAL) dan kewenangan untuk mencabut izin tersebut.

f. Jika saat ini pemerintah daerah tidak memiliki peluang untuk membuat Perda tentang pertambangan karena terhalang oleh Undang-Undang Nomor 3 Tahun 2020 Tentang Perubahan terhadap Undang-undang No. 4 Tahun 2009 tentang Pertambangan Mineral dan Batubara, maka peluang lainnya adalah dengan membuat Perda yang terkait dengan lingkungan. Perda ini diperlukan agar fungsi UKL-UPL dan AMDAL yang dikeluarkan oleh Dinas Lingkungan Hidup dan Kehutanan Kabupaten Klaten dapat dilakukan sesuai prosedur.

g. Perpres No. 70 Tahun 2014 berlaku selama 20 tahun sejak ditetapkan, tetapi pada aturan penutup ditemukan Pasal 86 Ayat 2 yang menyatakan bahwa peninjauan kembali rencana tata ruang kawasan Taman Nasional Gunung Merapi dilakukan 1 kali dalam 5 tahun. Hal ini sebenarnya dapat dijadikan pintu masuk terkait dengan permasalahan lingkungan yang terjadi pada wilayah zona lindung maupun zona budidaya dengan indikasi pemanfaatan dan penyalahgunaan izin lingkungan atau izin budidaya. Peluang untuk memberiklan rekomendasi pada saat peninjauan kembali.

Berdasarkan penelitian yang dilakukan, ditemukan beberapa pasal yang dapat dijadikan pintu masuk bagi Kabupaten Klaten untuk bisa melakukan pengawasan dan evaluasi terhadap pelaku pertambangan yang merusak lingkungan yang saat ini kegiatannya diawali dengan izin penataan perkebunan atau budidaya perkebunan tetap tercapai dengan tidak melakukan perusakan pada lingkungan.

\section{Kesimpulan dan Saran}

\subsection{Kesimpulan}

Aktivitas pertambangan pasir merapi di Wilayah Klaten Jawa Tengah telah berdampak pada rusaknya lahan pertanian dan lahan perkebunan yang tentunya mengancam ketersediaan lahan bagi generasi petani yang akan datang dan yang tentu juga akan berdampak pada ketersediaan pangan. Selain itu akivitas pertambangan telah merusak jalur evakuasi, mengganggu resapan air, ekologi, dan rawan longsor. Perpres Nomor 70 tahun 2014 tersebut menunjukkan secara detail dan jelas betapa sebenarnya realitas wilayah Kabupaten Klaten yang berada pada zona budidaya lebih dominan daripada zona wilayah pertambangan. Sejak tahun 2019 izin pertambangan di Kabupaten Klaten sudah tidak dikeluarkan. Izin pertambangan yang dikeluarkan beralih kepada pemberian izin bentuk kegiatan lain dalam bidang penataan lahan bekas sisa tambang ilegal yang ditinggalkan dan penataan perkebunan. Izin usaha perkebunan berbeda dari izin penataan lahan yang sebelumnya pernah dikeluarkan di Kabupaten Klaten. Izin penataan lahan hanya memerlukan izin lingkungan dari Dinas Lingkungan Hidup dan Kehutanan, Dinas ESDM provinsi dan izin usaha. Disisi lain, izin usaha perkebunan harus memiliki izin usaha dan izin lokasi dari Badan Pertanahan Nasional. 
Rekomendasi atau izin dari Badan Pertanahan Nasional tersebut dikeluarkan karena pada penataan perkebunan dengan lahan menggunakan tanah warga harus melakukan verifikasi dari Badan Pertanahan Nasional. Hal ini diperlukan agar lahan yang digunakan tersebut benar-benar dinyatakan tidak dalam keadaan sengketa. Apabila dalam kegiatan izin perkebunan itu ternyata harus menata lahan bekas tambang dan harus mengeluarkan material, pengusaha harus memiliki izin lingkungan dan mencari Izin Usaha Pertambangan Khusus (IUPK) ke Dinas ESDM Provinsi. Kebijakan izin usaha perkebunan diberlakukan dengan dasar Peraturan Menteri Pertanian No. 29/2016 tentang Perubahan atas Permentan No. 98/2013 tentang Perijinan Usaha Perkebunan. Dinas Lingkungan Hidup berperan dalam menerbitkan dokumen UKL dan UPL. Dokumen itu sebagai dasar terbitnya izin lingkungan.

\subsection{Saran}

Berikut ini merupakan beberapa saran yang dapat dilakuan dalam aktivitas penambangan agar dapat lebih ramah terhadap lingkungan dan tetap memiliki pengaruh secara sosial ekonomi:

a. Aktivitas penambangan perlu menerapkan prinsip penambangan yang ramah lingkungan

b. Menata pola pikir masyarakat akan pentingnya kesadaran pelestarian lingkungan kawasan merapi

c. Mencarikan solusi alternative ekonomi lain bagi masyarakat sekitar agar tidak tergiur melakukan penambangan terus menerus

d. Penegakan Hukum secara komprehensif oleh aparat penegak hukum didukung oleh dinas terkait dalam hal ini adalah Kementerian ESDM, Dinas Lingkungan hidup dan Kehutanan dan Dinas Pertanian Kabupaten secara bersama-sama dengan warga sekitar pertambangan dengan tetap mengedepankan kearifan lokal dan meninmgkatkan kepedulian terhadap kelestarian lingkungan.

\section{Daftar Pustaka}

Aditya, I. (2020). Penambangan Pasir Rusak Ekosistem Lereng Merapi. krjogja.com. Diakses pada 21 Juni 2021, dikutip dari https://www.krjogja.com/beritalokal/jateng/klaten/penambangan-pasir-rusak-ekosistem-lereng-merapi/

Aisyah, N., \& Purnamawati, D. I. (2012). Tinjauan Dampak Banjir Lahar Kali Putih Kabupaten Magelang Pasca Erupsi Merapi 2010. Jurnal Teknologi Technoscientia, 5(1), 19-30.

Deputi Sumber Daya Alam dan Lingkungan Hidup. (2014). Prakarsa Strategis Pengembangan Konsep Green Economy (Endah Murniningtyas, ed.). Jakarta: Kementerian Perencanaan Pembangunan Nasional / Bappenas.

Hamidi. (2004). Metode Penelitian Kualitatif. Malang: UMM Press. 
Irawan P. (2006). Penelitian Kualitatif \& Kuantitatif untuk Ilmu-Ilmu Sosial. DIA Fisip UI, Jakarta. 236p.

Jalal. (2019). Sexy Killers: Pertambangan dan/atau Pembangunan Berkelanjutan? Mongabay: Situs Berita Lingkungan. Diakses 18 Juli 2020, dikutip dari https://www.mongabay.co.id/2019/05/02/sexy-killer-pertambangan-dan-ataupembangunan-berkelanjutan-1/

Patiung dkk dalam Willyam Buli. (2018). Strategi Pengendalian Kerusakan Lingkungan Melalui Pembenahan Kelembagaan Pertambangan Batubara Tanpa Ijin Studi Kasus Di Kabupaten Muara Enim. Program Pascasarjana Universitas Lampung. Bandar Lampung

Prakoso, T. S. (2015). Penambangan Pasir Klaten : Belasan Usaha Penambangan Diduga Ilegal. Solopos.com. Diakses pada 21 Juni 2020, dikutip dari https://www.solopos.com/penambangan-pasir-klaten-belasan-usahapenambangan-diduga-ilegal-661001

Riskanita, D., \& Widowaty, Y. (2019). Upaya Pemerintah Daerah Mengatasi Kerusakan Lingkungan Akibat Alih Fungsi Lahan Berdasarkan Konsep Negara Kesejahteraan. Supremasi Hukum: Jurnal Penelitian Hukum, 28(2), 123-134. https://doi.org/10.33369/jsh.28.2.123-135

Uar, N. D., Murti, S. H., \& Hadisusanto, S. (2016). Kerusakan Lingkungan Akibat Aktivitas Manusia pada Ekosistem Terumbu Karang. Majalah Geografi Indonesia, 30(1), 88-95. https://doi.org/10.22146/mgi.15626

Wakik, A. K. (2020). Manfaatkan Pandemik Covid-19, Penambang Pasir Ilegal Di Klaten Diam-diam Beroperasi. Republik Merdeka. Diakses pada 21 Juni 2020, dikutip dari https://nusantara.rmol.id/read/2020/05/05/433486/manfaatkanpandemik-covid-19-penambang-pasir-ilegal-di-klaten-diam-diam-beroperasi

Widyastomo, B., \& Risyanto. (2013). Pengaruh Penambangan Pasir dan Batu Terhadap Kondisi Sosial Ekonomi Penambang di Kecamatan Kemalang Kabupaten Klaten, Provinsi Jawa Tengah. Jurnal Bumi Indonesia, 2(3), 270-276.

Yudhistira, Y., Hidayat, W. K., \& Hadiyarto, A. (2012). Kajian Dampak Kerusakan Lingkungan Akibat Kegiatan Penambangan Pasir Di Desa Keningar Daerah Kawasan Gunung Merapi. Jurnal Ilmu Lingkungan, 9(2), 76-84. https://doi.org/10.14710/jil.9.2.76-84

Peraturan Perundang-Undangan

Undang-undang Nomor 4 Tahun 2009 Tentang Pertambangan Mineral Dan Batubara

Undang-undang Nomor 3 Tahun 2020 Tentang Perubahan Terhadap Undang-undang Nomor 4 Tahun 2009 Tentang Pertambangan Mineral Dan Batubara

Undang-Undang Republik Indonesia Nomor 32 Tahun 2009 Tentang Perlindungan Dan Pengelolaan Lingkungan Hidup

Perpres Nomor 70 tahun 2014 Tentang Rencana Tata Ruang Taman Nasional gunung Merapi 
Peraturan Menteri Pertanian Nomor : 29 Tahun 2016 Tentang Perubahan Atas Permentan Nomor 98 Tahun 2013 tentang Perijinan Usaha Perkebunan.

Wawancara

Wawancara langsung dengan Kepala Dinas Lingkungan Hidup dan Kehutanan Kabupaten Klaten SRI HADIE

Wawancara dengan warga masyarakat di Kemalang Klaten

Wawancara dengan Bowo Hariyono warga Dompyongan yang terkena dampak penambangan pasir Merapi 